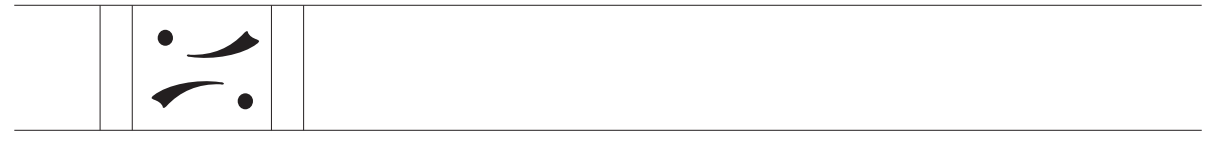

\title{
1 Some Reflections on Working-Class Ontology and Epistemology-or Why Teaching in Higher Education Needs to Be Move Concrete
}

\author{
K. ROBERT ISAKSEN \\ UiT The Arctic University of Norway
}

Abstract: Based on my own experiences with having one foot in academia and the other in construction, I reflect on how the tendential form of work among the working class affects their ontology and epistemology, and discuss what this may mean for teaching and learning in higher education. I attempt to write from both a working-class and middle-class perspective. This I do because it was the clashing of my working-class and middle-class experiences that caused me to reflect on forms of work in relation to ontology and epistemology; I need to present both perspectives to make sense of the argument.

Keywords: working class, ontology, epistemology, higher education, critical realism, autoethnography

\section{Introduction}

The general claim of this article is that the working class has a different ontology and epistemology than does the middle class. This comparative difference will primarily be related to teaching and learning in higher education. However, it also has implications for academic discourse in general, and in particular this text as it purports to present working-class ontology and epistemology. I must, therefore, first reflect on how the epistemology and ontology I argue for relate to academic 
texts, such as this one. Barker in her article "A White Working Class Perspective on Epistemology" introduces the topic such:

I was in the early stages of a research project, interviewing academics from working-class backgrounds, when Jake Ryan, co-author of Strangers in Paradise gave me a call for papers from working-class academics and suggested that I write something. [...] Since my research was still in the early stages I decided to write a personal essay about being a white woman from a working-class background in academia. When I attempted to begin writing I found that I could not separate my personal experience from my academic knowledge: my academic knowledge kept creeping in to my personal account. The reverse was true when I tried to write from a purely research standpoint. I spent several months attempting to write an essay without even creating an introduction or outline. [...] Gradually I also wondered about the overall problems some of us encounter when we try to write academically; translating our working-class knowledge and understanding into a format, structure, and language that was designed to deny our knowledge, experiences, realities, and values. I was already familiar with feminist and afrocentric approaches to epistemology. I began to think that a class-based approach was also needed. ${ }^{1}$

As Barker points out, the genre of academic texts is a convention belonging to the dominant social classes. Is it possible to write a working-class academic article, or is it then no longer an academic article? How much "middle-classness" does there have to be for it to still be an academic article? In this article, I wish to bring two parts of my thought into play, my middle-class background and my acquired working-class perspective to discuss working-class ontology and epistemology in relation to learning in higher education. I need both perspectives because it is the middle class that talks of (and has any interest in) abstractions such as "epistemology," but it is the lived experience of the working class that informs my argument. I present the more middle-class reflections and arguments in the italicized text, and I present the working-class experience and perspective in the non-italicized text. The one is not more important than the other, as I shall argue later.

In the following, I provide a narrative backdrop to explain how I have come to better understand working-class experience through my work as a ventilation installer. This backdrop will make sense of a short section on the claim and aims of this article. I then discuss the concept of class used in this article before turning to the main argument of the article, which is how working-class forms of work affect their ontology and epistemology. Following this there is a brief discussion about class conflict, which leads into the final section about what the prior theoretical discussions could mean for teaching and learning in higher education.

1 Judith Barker, "A White Working Class Perspective on Epistemology," Race, Gender éc Class 4, no. 1 (1996): 103-104. 


\section{My Narrative Backdrop}

I had been paying for the doctoral studies myself, first working in kindergartens and nurseries, and then shifting to construction, working as a laborer in a ventilation firm. When I started my full-time position at the ventilation firm, I also got a part-time assistant lecturer position at a university where I taught and supervised bachelor students in the social sciences.

Coming as I do from a middle-class background, I struggled to fit in among my new working-class colleagues. I understood their jokes but did not find them funny. Rather, I could see the racism and sexism that I know several of my academic colleagues would find repulsive, and that I could imagine would be hurtful to the people the jokes were about if they had heard them. What I experienced as machismo was perhaps the most difficult for it seemed to play a part in almost every social interaction. Though I never felt pressured to let go of my identity, I was motivated to understand my new trade and to vastly improve my skills with the mechanical tools, and to work well with my colleagues. I therefore sought to understand what the work was about and how best to carry it out. I had a steep learning curve, both in regard to carrying out my prescribed work and in better engaging in the social aspect of work.

I always worked together with an experienced colleague who had the relevant vocational training and many years of experience. At first, I was a sort of assistant, running to get equipment or materials. After several months, I was given greater license to fit ventilation tubes together and cut ventilation tubes to the correct specifications. After a couple of years, I continued to carry out these duties but was also in many cases simply given a blueprint together with a colleague and told to get to work. While learning how to carry out this new work I could not but help relate it to my previous experiences and to the academic work I was carrying out at the university. It is these thoughts of contrasting forms of work, ontologies and epistemologies, and implications for students in higher education that I shall discuss. After two years, I moved to another country to start a full-time position as an educational developer and in this position work to support faculty members in developing their teaching abilities. It is with a desire to keep in memory my experience and thoughts - and in this relatively new capacity as a teacher of university teachers-that I write this article.

It is clear that this was not in any way a predefined research project. I had no social scientific methodological or research ethical considerations when I started working as a ventilation installer. I was simply attempting to improve in my job. I have later, while writing this text, reflected on the relation between what I did 
and social scientific methodology and ethics. In short, I see a great deal of similarity between my method of data production and textual representation to that of autoethnography, in particular, of the conceptual type.

In conceptualist autoethnographies, personal stories become the mechanism for conveying and critiquing cultural experiences, breaking silences, and reclaiming voices. Conceptualist autoethnographies use first-, second-, and third-person narration and are highly reflexive. Conceptualist texts question the role and purpose of research and writing, the formality of research texts, the role of the author as artist, and the lessons that autoethnographies can offer writers and readers. ${ }^{2}$

There are also similarities and differences between my "methodology" and what has been termed workers inquiry — named so after Marx's questionnaire to the French working class in 1880. ${ }^{3}$ Marx's survey was designed not only to gather information directly from the working class themselves but also to "further generate questions in the minds of the workers surveyed." Since then several other approaches to workers inquiry has been suggested and critiqued, for example, inviting workers to share their lived experience through life narratives and carrying out participatory action research. ${ }^{5}$ The purpose of workers inquiry has been that the members of the working class learn about themselves and their class relations, and through this produce the necessary means for emancipation. My primary audience here is not the working class in that I am assuming you, the reader, are not working-class (at least not in most part any longer). The political goal here is not specifically to emancipate the working class, but rather to invite members of the middle class who are in positions of power as teachers in higher education to meet working-class students where they are. Exactly what I mean by this will be clearer later.

As mentioned above, I felt very uncomfortable in the beginning with the things my colleagues sometimes said and did. At the same time, I came to recognize that I did not like it based on my middle-class perspective. As feminists and postcolonialists might point out; why should these values be the correct ones? Not only were my values from a Western middle-class perspective, so

2 Tony E. Adams, Stacy Holman Jones, and Carolyn Ellis, Autoethnography (Oxford: Oxford University Press, 2015), 88.

3 Asad Haider and Salar Mohandesi, "Worker's Inquiry: A Genealogy," Viewpoint Magazine 3 (2013).

4 David Silverman, Qualitative Methodology \& Sociology: Describing the Social World (Aldershot, UK: Gower, 1985), 194-195.

5 Jamie Woodcock, “The Workers' Inquiry from Trotskyism to Operaismo: A Political Methodology for Investigating the Workplace," Ephemera: Theory and Politics in Organization 14, no. 3 (2014); 493-513. 
too were the explanations I sought to provide of my colleagues' behavior. For example, my initial belief was that the tendency to speak harshly was because of personal insecurities. I could see that my analyses were from my middle-class perspective and that I did not yet understand my colleagues on their own terms. I considered it akin to explaining women's behavior from my perspective as man. I therefore sought not only to better understand how to do my job and how to engage socially, I also sought to be more like them and think like them so I could better understand them.

Some readers may take the above as criticism on my part of the working class. It is rather a criticism of the middle class, or of myself and others like me who judge the working class from their middle-class perspective. I am here holding a momentary pluralism. Following MacIntyre and Jaeggi, I argue it is valuable to understand other's perspectives and values on their own terms, and that it is also a possibility to move beyond pluralism via immanent critique. ${ }^{6}$ In this article, however, primarily the pluralism will be present to give further voice to the working class. This also means that I will vent some of my frustrations.

One of the things I most appreciated about my work in ventilation was the physical and visual satisfaction it often provided at the end of the day. As I drive around town, I see and can point out to my family the many places I have installed ventilation or provided service to make life better for the police, moviegoers, schoolchildren, homeowners, and so on. I naturally compared this to my academic job. When marking students' papers, I came to note a single grade after thirty minutes to an hour. The grade quickly disappears for me forever as I electronically send in the results to the administration. Writing a single academic paper takes months of reading, writing, feedback, and rewriting. Most of this is done sitting in one or a couple of places. The same goes for architects and engineers who spend many hours drawing and redrawing, calculating and double-checking the calculations. It is heavy cognitive work but comparatively little physical work. I and my ventilation colleagues have a blueprint in the morning and by the end of the day, we see clearly what we have created. The end product of my academic work is always comparatively small compared to the amount of time invested in it. This is not to say I value academic work less, for I love teaching, thinking, and developing ideas, but it does provide much less physical and visual gratification on the whole.

6 Alisdair MacIntyre, Three Rival Versions of Moral Enquiry: Encyclopedia, Genealogy and Tradition (Notre Dame, IN: Notre Dame University Press, 1990); Rahel Jaeggi, Critique of Forms of Life (Cambridge, MA: Harvard University Press, 2018). 


\section{The Claim and Purpose(s)}

The main argument in this article is that social structure affects praxis which in turn affects ontology and epistemology, and that the working class have a different ontology and epistemology than does the middle class and this needs to be accounted for and understood if we are to support, rather than undermine, the effort of students with a working-class background in higher education. It is well known that people from working-class backgrounds are less likely to participate in higher education and are less likely to complete their studies if started. Bernstein has argued that it is because of differences in linguistic forms, or codes. ${ }^{8}$ I do not disagree with this, but I shall argue that the difference in modes of discourse derives in part from a difference in ontology and epistemology, which derives from a difference in praxis, which in the end derives from a difference in social role, position, and power. I am not claiming with certainty that these causal relations exist. Rather, it is a proposal of one causal mechanism as an addition to others that have already been proposed about why students with a working-class background struggle to a greater extent in higher education than do students with middle-class backgrounds. ${ }^{9}$

I also have a desire to affect change. There is also a part of me that is frustrated that we don't talk more about class in relation to teaching and learning in higher education. Why don't we do this? Who decided it is of no relevance? I'm in a social and economic position where I have the freedom to think abstractly and at a distance, but when I think of my working-class colleagues and the way they are viewed in society there is a part of me that gets angry and is unsatisfied with mere reflection. I wish for greater equality and inclusiveness in higher education and academia generally.

7 Pierre Bourdieu, Distinction: A Social Critique of the Judgement of Taste (Cambridge, MA: Routledge and Kegan Paul, 1984), 157-160; Mike Savage, Niall Cunningham, Fiona Devine, Sam Friedman, Daniel Laurison, Lisa McKenzie, Andrew Miles, Helene Snee, and Paul Wakeling, Social Class in the 21st Century (St Ives, UK: Penguin Random House, 2015), 221-232; Katherin Barg, Simon Benham-Clarke, and Anna Mountford-Zimdars, "Investigating the Imagination of Possible and 'Like-to-Avoid' Selves among Higher Education Students from Different Socioeconomic Backgrounds at a selective English University," Social Sciences 9, no. 67 (2020): 1-3.

8 Basil Bernstein, "Elaborated and Restricted Codes: An Outline," Sociological Inquiry 36, no. 2 (1966): 254-261.

9 Barg, Benham-Clark, and Mountford-Zimdars, "Investigating the Imagination," 3-5. 


\section{The Concept of Class}

The concept of class is highly contested and there is a multitude of conceptions of class. For Marx, social class is decided by economic relations of production. Bourdieu disagrees and argues that social class is defined by the relative amount and composition of economic, cultural (also called informational), and social capital. ${ }^{10}$ Though there is conceptual disagreement between Marx and Bourdieu, there is also overlap in some of their claims, and the argument proposed here has similarities to arguments made by both, for example, the embodied part of Bourdieu's cultural capital. Bourdieu defines this as "external wealth converted into an integral part of the person, into a habitus, [and] cannot be transmitted instantaneously ..."1 Embodied cultural capital, as part of habitus, provides the backdrop for learning and in turn becomes the outcome for "long-lasting dispositions of the mind and body". ${ }^{12}$ However, I do not wish to align fully with Bourdien because of theoretical obstacles to habitus, ${ }^{13}$ and because of his de-emphasis on the relational aspect of class. From a Marxist perspective, forms of work affect forms of knowledge. ${ }^{14}$ This also is a position close to the one I propose. However, Marx and Marxist-inspired thinkers, such as Lukacs ${ }^{15}$ and some feminist standpoint theorists, have focused on a common standpoint of political awareness deriving from economic and social positionality and praxis. ${ }^{16}$ The focus in this article is more about a common ontology and epistemology deriving from similar forms of work which need not, and perhaps usually are not, at the forefront of personal or political awareness. Furthermore, Marx's analysis was of a specific geo-historic context. Though I believe many of his insights are still relevant today, the economic

10 Pierre Bourdieu, "What Makes a Social Class? On the Theoretical and Practical Existence of Groups," Berkeley Journal of Sociology 32 (1987): 1-17; Pierre Bourdieu, "The Forms of Capital," in Handbook of Theory and research for the Sociology of Education, ed. John G. Richardson (New York: Greenwood Press, 1986), 241-258. Background after Mannheim and Bourdieu," Social Epistemology 11, no. 2 (1997): $150-153$.

14 Cynthia Lai, “The Role of Practice in the Marxist Theory of Knowledge," The 80's2, no. 1 (1981), https://www.marxists.org/history/erol/ncm-8/cwppractice.htm\#: :text= The $\% 20$ Marxist $\% 20$ line $\% 20$ of $\% 20$ cognition, and $\% 20$ methods $\% 20$ of $\% 20$ the $\% 20$ proletariat.

15 György Lukács, History and Class Consciousness: Studies in Marxist Dialectics(London: Merlin Press, 1971 [1920]), 149-150.

16 Tracy Bowell, "Feminist Standpoint Theory," The Internet Encyclopedia of Philosophy, 2020, https://iep.utm.edu/fem-stan/. 
relations of production are in many cases much more nuanced and complex now than in his time and an absolute structure of relations between classes is much more problematic. For several years I was a manual laborer, an academic, and a stockowner all at once. Though both Marx and Bourdieu have arguments that converge to some extent with mine, I shall not align myself here with either of their conceptualizations of class. Even though I consider as insightful both Marx's emphasis on economic relations and Bourdieu's ideas on forms of capital they are in conceptual disagreement and I see no clear way to synthesize or choose between them at this point. Therefore, I rather seek to draw attention to a tendential characteristic of the working class, whether as defined by the conceptualization of Marx or Bourdieu. The tendential characteristic is that these people's work is more physical than that of the middle class, which in turn is tendentially more abstract and cognitive. On a construction project, for example, engineers and architects represent the more theoretical aspects of the project, and the craftsmen and laborers represent the more physical aspects. Thus, engineers and architects, in this analysis, can be said to do middle-class work, and craftsmen and laborers carry out working-class work. My focus here is with "traditional" working class in the form of craftsmen, but I argue that such a tendency in physical work can be found in other common conceptualizations such as blue-collar, much of pink-collar, rural, and lower socioeconomic status. I would also suggest the work of many indigenous peoples could be included here, though this again would depend to some extent on social standing within the given society and whether the individual had comparatively more experience with organizational or physical work.

The talk of "comparatively different tendencies" comes from my critical realist take on etiology. Causality for critical realists is not found at the level of events but at the deeper level of mechanisms. The etiology is one of causal mechanisms that usually cannot be observed and which cause events that can be observed. Critical realism holds a multicausal view of society. This means that though one mechanism is in action, there may be others counteracting its causal effect (like wind counteracting the gravitational pull on a leaf), and therefore clear regularities of cause and effect are unlikely to be observed in society and in general outside of controlled experiments. ${ }^{17}$ A central goal of critical realist-inspired research is therefore to hypothesize, through a mode of inference called retroduction, causal mechanisms that could, if they existed, provide part of an explanation of observed comparative differences at the level of events. ${ }^{18}$

17 Roy Bhaskar, Scientific Realism and Human Emancipation. 2nd edition. (Abingdon: Routledge, 2009), 105-113.

18 Tony Lawson, "Economic Science without Experimentation," in Critical Realism: Essential Readings, eds. Margaret Archer, Roy Bhaskar, Andrew Collier, Tony Lawson, and Alan Norrie (Abingdon: Routledge, 1998), 144-157. 
Though I do not have a clear-cut definition of the working class, only "a comparative tendency to physical rather than conceptual labour based on tendencies in economic relations," I still wish to apply this polysemic concept because of its connotative connection to, for example, the work of Marx and Bourdieu, and to public and political discourse. There is enough convergence that "class" becomes an important and meaningful construct. (I do not in this analysis include the upper class because I have no personal experience of this group with which to analyze autoethnographically.) Though I believe there is a distinction between primarily physical and theoretical work, I do not view it is as an absolute and clear-cut distinction, but rather as a gradient and tendential one. For example, although an engineer's work is less theoretical than most philosophers, it is more theoretical than that of a ventilation laborer, which in turn is more theoretical than that of demolition workers. There are also differences within groups in that individuals may take a more theoretical approach than others. Some of my colleagues, for example, may use the Pythagorean theorem (and recognize it as such) when considering how long to cut ventilation tubes with a disc grinder. Other colleagues hold a bended tube in the air and measure by observation how long the two ventilation tubes on the side should be. Both work. Since the distinction between theoretical and physical work is not absolute, the distinction between working-class work and middle-class work also is not absolute. What I shall attempt to describe in this article are comparatively different tendencies in ontology and epistemology brought about by comparatively different tendencies in forms of work.

It is important to note that my colleagues whom I refer to as working class do not do so themselves. They refer to themselves as middle class. They understand the term "class" as related to economic status, and do not consider themselves to be either the poorest or the richest, therefore "middle class." I respect their choice of interpretation and see value in interpreting class according to economic status, but also believe that relating class to the characteristic of praxis can help make sense of some of the frustrations they and others experience.

My gradient approach to class has implications for this article. I have attempted to write from a middle-class perspective in the italicized text and from a working-class perspective in the regular text, but this absolute dichotomy is not an accurate representation. However, the software I have to write does not allow for degrees of italicization, and the clear distinction may in any case be useful to make the tendential differences more apparent. 


\section{Ontologies and Epistemologies}

When installing a 3-meter-long metal ventilation tube I, and everyone else, can clearly see whether or not the bubble in the spirit level is within the two vertical lines to make certain the ventilation tube is perfectly horizontal. In many cases, we can clearly see if the tube is horizontal even without any instruments. It is either right or it is wrong. This is vastly different from the job of the architect or engineer, or perhaps especially academics. When working on my own papers or that of my students, I may sense that something is somehow not quite right, but I cannot see it clearly. It may go several days, weeks, or more before I understand what is missing or out of place. In many cases, I need others to see for me. My argument is that people in working-class jobs experience more directly the reality with which they engage than do people with middle-class jobs. My colleagues enjoy whenever they can point out the impossibilities that architects or engineers have theorized in their blueprints or calculations. In addition to such enjoyment is a frustration that the architects and engineers who draw the blueprints have power over them by having the final say about their work and make more money than they do: "They get paid [roughly 100 dollars] an hour. They hardly do any work, just sitting around in their offices chatting and drinking their fancy coffees." This is contrasted with my colleagues' views about what counts as "real work," meaning manual labor, which is more physically strenuous and exhausting. Though several of my colleagues have told me how they found school challenging at times, it is their own daily work that seems to figure clearest when they discuss what counts as real work.

Why is ontology and epistemology discussed among philosophers and not among construction workers? From a working-class perspective, the answer might be that it is because philosophers are so far removed from reality that they start questioning what reality is and what one can know. This was Heidegger's critique of Descartes and philosophy after him. ${ }^{19}$ As a ventilation installer, all I need to know is whether the ventilation tubes are put together properly or not. This may sound like a form of pragmatism, but pragmatism takes an explicitly agnostic stance to the question of external reality and final truth. ${ }^{20}$ This is not the position of the craftsmen and laborers as I know them. I think the best philosophical descriptions of working-class epistemology would be objectivism, where

19 Martin Heidegger, Being and Time (Oxford: Blackwell, 1962), 89-134.

20 William James, “The Sentiment of Rationality," Mind 4, no. 15 (1879): 317-346; Richard Rorty, Philosophy and the Mirror of Nature (Princeton, NJ: Princeton University Press, 1979), 373-379. 
it is assumed without question that reality can be known directly. ${ }^{21}$ Some might use the term "positivism," but this perspective views science as absolute truth, and this does not sit well with many working-class people, a point which I shall turn to shortly.

In addition to an objectivist epistemology, I argue that the working-class ontology is of specific and concrete things and not about abstract ideas or concepts. Again, I see this as a consequence in large part of the work carried out. The role of working-class people in capitalist society is to carry out the material work designed by the middle and upper classes. It is work related to specific entities in time and space, not about abstract generalities, systems, or structures. I therefore define this working-class ontology and epistemology as a concrete objectivism. This can be contrasted with what could be termed the abstract objectivism found in scientism. Scientism is the view that only science, and by implication scientists, can be a trusted source of knowledge and that science provides facts which are indisputable, or close to being so. ${ }^{22}$ The abstract nature of scientism is not a position ascribed to by my colleagues or other working-class people I have talked to. The clearest example is in relation to climate science. It must first be stated that not all of my colleagues completely disagree with what is described as the scientific consensus on anthropogenic climate change, though the relative distrust is clear in comparison to my middle-class colleagues. One of my ventilation colleagues put it well when he rhetorically questioned how a computer simulation can accurately and with perfect certainty describe future reality. He explained he did not understand how anyone could know such complex matters. In all the discussions he had heard about climate change on the radio and television, he had never heard anyone explain it in a manner he could understand, and he being a grown man and capable in many ways felt he could not do anything but stay agnostic or perhaps a little doubtful about the topic because of this. My take from this is that his work, dealing with specific things that can be directly seen and felt, tends to lead to a concrete objectivism which means that abstractions as presented by climate scientists, and scientists generally, do not make sense and therefore cannot be fully trusted. I understand my colleagues' resistance to claims about reality which he does not fully understand but is expected to accept based on the assertions of scientists, especially since the claims have consequences for his life choices. I am in the current analysis setting aside economic and psychological motivations that may be found among the working class in relation to not accepting climate science.

21 Richard, J. Bernstein, Beyond Objectivism and Relativism: Science, Hermeneutics, and Praxis (Philadelphia: University of Pennsylvania Press, 1983), 8-12.

22 Bernstein, Beyond Objectivism and Relativity, 48. 
Another practical outcome of the concrete objectivism is that my colleagues consider people as the primary causal factors, not abstract systems or structures. When things go wrong it is the reflexive reaction of my colleagues to put the blame on people rather than the systems they inhabit. It is not that my colleagues cannot talk about systematic problems or injustices (they personally experience many of them) but when they do, they always present it in a way where it is the people in the systems who are the problems or it is the people who made the systems that are the problem. There is very little consideration of unintended consequences emerging at complex levels of social interaction. As mentioned earlier, I am not here making the claim that the concrete objectivism is the only reason that the emergence of unintended consequences are considered among the middle class and to a much lesser extent among the middle class. For example, access to-and participation in-higher education plays a role. However, Latour's observations about the similarities and differences of academic social critique and conspiracism provides support for the possibility of such an ontology and epistemology.

"In both cases [social critique and conspiracy theory], you have to learn to become suspicious of everything people say because of course we all know that they live in the thralls of a complete illusion of their real motives. Then, after disbelief has struck and an explanation is requested for what is really going on, in both cases again it is the same appeal to powerful agents hidden in the dark acting always consistently, continuously, relentlessly. Of course, we in the academy like to use more elevated causes-society, discourse, knowledge-slash-power, fields of forces, empires, capitalism-while conspiracists like to portray a miserable bunch of greedy people with dark intents [...]"23 A final example of the concrete objectivism can be seen in my colleagues' politics. Though there are individual differences among my working-class colleagues, the general approach to politics is one of absoluteness and individuality. It is claimed that women are worse drivers and are hysterical. Immigrants and anyone on benefits are lazy. These are the sorts of claims I have heard from my working-class colleagues. When pressed on the issue, they admit that not all women are bad drivers or hysterical, and not all immigrants and people on benefits are lazy. My colleagues are more nuanced than they may at first seem, but the original claims reflect, to me, the objectivist part of their epistemology.

Their concrete ontology can be seen as one reason my working-class colleagues often prefer capitalism over socialism, even though socialism may be in their greater interest; they can better relate to the individualist view of society in capitalist thought whereas the more collectivist view in socialist thought is something

23 Bruno Latour, "Why Has Critique Run Out of Steam? From Matters of Fact to Matters of Concern," Critical Inquiry 30 (Winter 2004), 229. 
they find relatively alien. They relate to their personal experience and that of friends and family, but much less so a "global village." Relatedly, the discourse of the left, and Marxism in particular, is abstract. For those who wonder why socialism is not more accepted among the working class, one reason may be the abstract language in which society is discussed. I am not claiming that capitalist hegemony plays no role, I am rather suggesting that in addition to such "outward threats," the very discourse of the left itself may alienate those they seek to support as it comes from another ontology.

\section{Class Conflict}

One of the experiences I immediately recognized as a breakthrough in relation to understanding my working-class colleagues came one day while working with a seasoned ventilation installer. I had been working as a ventilation installer for a little over a year. We were installing ventilation in a large factory hall. There was no one there but us and we could therefore work uninterrupted and complete our task without any interruptions. At one point, I was up in a lift waiting for my colleague to bring a ventilation tube and suddenly came to realize the feeling of autonomy we often felt and enjoyed. At the same time, I recognized how this autonomy would feel damaged or even completely taken away if the engineer responsible for the project was to come in through the door and into this space. I was aware that technically we were never fully autonomous for we had responsibilities to the engineers who had hired us and instructed us of what to do, yet full autonomy is the experience we often have because we do not relate in our day-to-day activities with those who have power over us.

In a sense, I felt like my colleague and I were kings over the space, not in the sense of being above other people but in the sense of "owning" the space. This is the same as the feeling I have in my private office at university or when teaching in a class. In that moment I realized that if the engineer were to come in through the door, we would immediately feel our autonomy reduced and our space taken from us. We would feel less than we did just a minute before. We might be asked to explain why we did not follow the blueprint perfectly. We could explain our choices by pointing out that there were some obstacles that were not included in the blueprint, but the feeling would be that we were the ones being questioned about our choices. Losing our feeling of autonomy is not just a point about emotions, it is about personal identity. At the time of thinking about these things, I could better understand some of the awkward interactions I had experienced between my seasoned colleagues and the engineers and project managers. Before this, I had just felt 
my colleagues were being difficult for no other reason than personal insecurities. Based on such experiences, I can better understand that people from working-class backgrounds may often have the feeling that their knowledge and autonomy is undermined by politicians, journalists, doctors, engineers, architects, scientific experts on the radio, and so forth. Didier Eribon puts it well when he says that the contempt for the working class "is everywhere, almost conditioned, always a bit pejorative, demeaning, contemptuous or mocking. Even if it's not violent, there's a superiority. I feel attacked by this. When people speak of the concierge, that's my grandmother; or the factory worker, that's my grandfather; and the cleaner, my mother $[\ldots]$ What was difficult was not being gay but being working-class." ${ }^{24}$ The final statement by Eribon is of course an exaggeration, but an exaggeration with a point. Similar experiences are recounted by others. Carolyn Law writes of her time as an undergraduate student,

My ambition then was to become an English teacher. I admired my high school teachers; I liked their lives (what I could see of them). My mother, I know, was proud of me and glad that I was doing well in a world she had never known. What she could not have guessed, though, was that in the course of my teacher training, I learned, through myriad covert (and some not so covert) pressures and practices, to feel increasingly ashamed of my home, of my family. Again and again, I heard that children who do not read, whose parents work too hard and who have little time or skills to read to them, whose homes are not "literate" but oral and pretty nonverbal as well, children who have never been taken to an art museum or who do not have library cards, these are the ones at risk, the ones most likely to fail (be failed by?) the traditional academic setting, in practical terms, the ones who make a teacher's job so daily frustrating $[\ldots]$ It never occurred to me to question the implicit classicism and institutional biases that view the child as the problem, not the system or the curriculum. ${ }^{25}$

While it is socially unacceptable among the middle class to have racist or sexist views, a superior view about the working class, and in particular the white working class, is not a primary problematic. In the field of social epistemology, for example, there are today growing concerns about epistemic injustice. In short, epistemic injustice looks at how and why certain individuals and groups receive

24 Kim Willsher, "Didier Eribon, Writer: 'What Was Difficult Was Not Being Gay but Being Working-Class'," The Guardian, May 27, 2018, https://www.theguardian.com/ books $/ 2018 / \mathrm{may} / 27 /$ didier-eribon-interview-returning-toreims-working-classcoming-out--memoir.

25 Carolyn Leste law, "Introduction," in This Fine Place So Far from Home: Voices of Academics from the Working Class, eds. C. L. Barney Dews and Carolyn Leste Law (Philadelphia, PA: Temple University Press, 1995), 2-3. 
injustice specifically related to their knowledge. Even in these discussions, white working-class views are not discussed. In a recent edited volume on epistemic injustice, there are sections on epistemology from feminist, postcolonial, and queer perspectives, all of which are important. ${ }^{26}$ Discussions regarding epistemological perspectives of the white working class are absent. In the chapter on "Ideology," there is a brief discussion of the historical roots of this concept for analyzing classes, but then the focus turns to issues of race and knowledge, which is of course also important.

The middle class has in many cases little need to worry about what the working class thinks of them because of their relative power, whereas the working class must always in some way relate to the criticism they receive at the hands of the middle class. The way the working class may relate to such criticism can take various forms, for example, by assimilating the criticism of the middle class which may further make the working-class person feel devalued as an individual and become motivated to pass on the blame to others. I am not here claiming that the middle class has perfect autonomy, but the comparative difference, in my experience, is palpable.

\section{The Working Class and Learning in Higher Education}

I find the criticism, of some people from the middle class, that people from the working class are less intelligent and perhaps should not even be allowed to participate in politics to be lacking in reflexivity about the tendential role the middle class plays in the educational system. ${ }^{27}$ Reflecting on the "massification" of higher education, Biggs and Tang argue that the "overall lowering of academic standards" has occurred because of an increase of students who are not the "brightest and most committed. ${ }^{28}$ I have heard similar claims from some colleagues in higher education. It is expected that because we managed, the academic winners, then if people fail according to criteria that suited us, it is because they are either lazy or lacking in commitment. Though Biggs and Tang wish to contribute to the improvement of teaching in higher education to support these students, they approach the issue in a derogatory manner that assumes lack of intelligence and commitment. I rather agree with Moffett, Bourdieu and Hasan

26 Ian J. Kidd, José Medina, and Gaile Pohlhaus, Jr., The Routledge Handbook of Epistemic Injustice (Oxon, UK: Routledge, 2017).

27 E.g. Jason Brennan, Against Democracy (Princeton, NJ: Princeton University Press, 2016).

28 John Biggs and Catherine Tang, Teaching for Quality Learning at University (Maidenhead: McGraw-Hill, 2011), 4. 
that the working class has a more concrete and direct form of discourse, while the middle class has a more abstract one which is the same as the discourse conventions in formal education. ${ }^{29}$ My further argument is that the concrete objectivism of the working class is one of the causal mechanisms to affect the form of discourse that is employed among the working class (and which ontology and epistemology is likely itself in part affected by working-class discourse).

Hasan has provided explanations for the difference in discourse by referring to the early forms of discourse developed by children in their relations with their mothers and the form of discourse found in schools. In her article "The Ontogenesis of Decontextualized Language," it is reported that the working-class mothers in her study had a more directing tone, telling their child what to do in a primarily unidirectional manner and that conversations were not taken from the perspective of the child. ${ }^{30}$ This was contrasted with the approach taken by middle-class mothers where there was comparatively more openness to letting the dialogue follow the interests and questions of the child. Hasan demonstrated that the working-class children do indeed have generalizations and abstractions, but they are often imposed upon them from the parents.

Peckham referring to his own working-class childhood and the work of Basil Bernstein explained that the unidirectionality in the discourse of his working-class father was not necessarily because he was lazier or more selfish than middle-class parents. ${ }^{31}$ Peckham explained that his father was preparing him for the only world he knew; one where you are told what to do by those with more power. My own experience was also that after a long day of extremely loud noises on construction sites, I desperately needed my children to be quiet when I came home, which of course they neither were nor could be. The middle class, on the other hand, have jobs that are tendentially more cognitive and conceptual. The architect envisages on a grander scale than does the construction worker. As does the academic. And the politician. Indeed, it is their job to do so, and I argue this form of work affects their ontology and epistemology, and the ones their children are tendentially socialized into. Hasan argued that

29 James Moffett, Teaching the Universe of Discourse: A Theory of Discourse (Boston, MA: Houghton Mifflin, 1968), 57-59; Bourdieu, Distinction, 45; Ruqaiya Hasan, "The Ontogenesis of Decontextualized Language: Some Achievements of Classification and Framing," in Semantic Variation: Meaning in Society and Sociolinguistics, ed. Jonathan J. Webster (London: Equinox, 2009), 403-432.

30 Hasan, "Ontogenesis of Decontextualized Language," 420-425.

31 Irvin Peckham, "Complicity in Class Codes: The Exclusionary Function of Education," in This Fine Place So Far from Home: Voices of Academics from the Working Class, eds. C. L. Barney Dews and Carolyn L. Law (Philadelphia, PA: Temple University Press, 1995), 265-266. 
because the working-class child is not as much supported at home in learning to generalize and abstract from their own experience, the abstract level of discourse becomes more alien than concrete discourse, whereas children of middle-class mothers have more experience with learning how to abstract from their own immediate experience and are therefore comparatively more comfortable with abstract discourse. ${ }^{32}$ Importantly, in relation to formal education, Hasan noted that the teachers she observed followed the conventions of the working class in not opening up for following the children in their interests (presumably because there are too many students in a class and the teachers need to have control) while still speaking and evaluating in a primarily middle-class form of abstract discourse. It is not surprising that this makes it incredibly difficult for children from a working-class background to do well in school when they are expected to already have middle-class conventions but are not able to develop them at home or at school. Such abstract discourse only intensifies when moving into higher education. Thus, the concrete objectivism of the working class is given less opportunity to develop so as to understand more abstract ideas and ways of thinking as are learned in school and especially higher education. It, therefore, seems unfair when the working class are blamed for not understanding abstract science since they have had much less opportunity to understand abstract discourse and thought in general, and science in particular.

As mentioned previously, those with working-class backgrounds generally struggle to a greater extent in higher education than do students from middle-class backgrounds. Whether the goal is to improve social mobility or to help working-class students achieve emancipation (at present I shall not argue for the one or the other), it seems that a greater focus on the concrete would be a beneficial move to help working-class students learn and understand, also about themselves and their own context. Radcliffe applied Moffett's abstraction model, which recommends to start writing from personal phenomenological experience, then abstracting from pure phenomenology to narrative, from narrative to expository argument, and finally from exposition to theoretical argument. ${ }^{33}$ She explained that in her teaching experience, she had never seen such interest and increased ability among her inner-city students to write generalizations and argumentative text. ${ }^{34}$ Oskar Negt has developed a theory of bildung for and of the working class, and, as with Radcliffe, recommends by starting from the personal concrete experience of the working-class learner and then inviting them to consider generalizations and

32 Hasan, "Ontogenesis of Decontextualized Language," 427-430.

33 Barbara Radcliffe, "Narrative as a Springboard for Expository and Persuasive Writing: James Moffett Revisited," Voices from the Middle 19, no. 3 (2012): 18-24.

34 Radcliffe, "Narrative as a Springboard," 23-24. 
theoretical abstractions based on these. ${ }^{35}$ This, it should be noted, is in many ways similar to what middle-class mothers in Hasan's study did. The point here is not to socialize working-class people out of their ontology and epistemology, but rather to be better acquainted with abstract thought and discourse which may benefit them, and as Moffett has stated, "No greater value is ascribed to one level than another. Both concreteness and abstraction are dangerous and valuable. ${ }^{36}$ As mentioned above, Hasan noted that the working-class children did have generalizations and abstractions but that these were less connected to their own experience. Similarly, the concrete is not completely absent from middle-class thought and discourse, with academic discourse, for example, to a greater or lesser extent punctuated with concrete examples. There is a comparative difference, but the difference is not of a necessary mutual exclusivity.

Learning, according to Moffett, is a continual "two-way street" between the concrete and the abstract. ${ }^{37}$ Following Moffett-though he did not put it in these terms - there is a mutual dialectical necessity of the abstract and the concrete: Without concrete experience there could be no abstract thought, and without abstract thought concrete experience would not make sense. ${ }^{38}$ The middle class has a tendentially closer connection to the abstract, the working class has a tendentially closer connection to the concrete. In my academic work, I have experienced that students coming from working-class backgrounds, whether from Europe or, for example, the Middle East, find it more natural, almost automatic, to present examples along with abstract ideas, something which some of the middle-class students who use academic buzzwords without understanding them could learn from. Rather than antagonism and frustration, there could be a higher degree of mutual appreciation and understanding, which I believe would improve the learning of both working-class and middle-class students in higher education and the democracy of academic discourse in general. Teaching by using more concrete examples, experiences, and narratives to teach abstract concepts could be beneficial for most students, and especially those from working-class backgrounds who are so often alienated from higher education. The concrete and abstract are, of course, only one aspect of tendential differences between the working class and middle class, another is tendentially different values, for example, and these may clash in higher education.

35 Kerstin Pohl and Klaus-Peter Hufer, "An Interview with Oskar Negt," International Labor and Working-Class History 90 (Fall 2016): 206-207.

36 Moffett, Teaching the Universe of Discourse, 25.

37 Moffett, Teaching the Universe of Discourse, 29.

38 John Dixon, "Dialogue and Theory: On James Moffett's Work in English Teaching and Language Education," Teaching English 17, no. 3 (2010): 281-282. 


\section{Final Reflexive Comments}

Now a final reflexive note about the relation between my own position and the ontology and epistemology I propose on behalf of the working class: To what extent is the ontology and epistemology I propose merely an implicit reflection of the Marxist-and Aristotelian-inspired epistemology and ontology in critical realism which I ascribe to? To be sure, I did not conceive of the proposed working-class epistemology by drawing out implications or similarities from these perspectives. Just as certainly, my perspective certainly affects what I see. From a critical realist perspective, however, this does not necessarily lead to a subjectivist cul-desac. According to Bhaskar, social and knowledge structures not only constrain us in various ways, they also enable us. ${ }^{39}$ Just as language constrains thought and action in various ways, so it also enables thought and action in other ways that would not be possible without language. From such a perspective it may be the case that the ontology and epistemology I have appropriated may be the reason I see what I see (even though it is in fact mistaken), or it may be that it is part of the reason that I see what I see (and it is to a greater or lesser extent an accurate expression of their ontology and epistemology).

Why did this article end with so much italicized text? As mentioned previously, I am writing for a middle-class audience and cannot therefore completely disregard academic conventions. If I am completely honest, however, it is also because I haven't been able to completely escape my own academic training and past experience. There is also a part of me that is prideful and wants to be accepted by academics. Finally, my genuine enjoyment of thinking in the abstract has also played a primary role.

\section{Acknowledgments}

I want to thank Irvin Peckham, my colleagues in the Philosophy of Education Research Group at UiT The Arctic University of Norway, and the two anonymous reviewers for their varied but always valuable contributions. Most importantly, however, I want to thank my colleagues who taught me how to install ventilation and who never gave up on the awkward academic among them.

39 Bhaskar, Scientific Realism, 122-129. 


\section{References}

Adams, Tony E., Stacy Holman Jones, and Carolyn Ellis. Autoethnography. Oxford: Oxford University Press, 2015.

Barg, Katherin, Simon Benham-Clarke, and Anna Mountford-Zimdars. "Investigating the Imagination of Possible and 'Like-to-Avoid' Selves among Higher Education Students from Different Socioeconomic Backgrounds at a Selective English University." Social Sciences 9, no. 67 (2020): 1-20.

Barker, Judith. “A White Working Class Perspective on Epistemology.” Race, Gender \& Class 4, no. 1 (1996): 103-118.

Bernstein, Basil. "Elaborated and Restricted Codes: An Outline," Sociological Inquiry 36, no. 2 (1966): 254-261.

Bernstein, Richard J. Beyond Objectivism and Relativism: Science, Hermeneutics, and Praxis. Philadelphia: University of Pennsylvania Press, 1983.

Bhaskar, Roy. Scientific Realism and Human Emancipation. 2nd edition. London: Routledge, 2009.

Biggs, John, and Catherine Tang. Teaching for Quality Learning at University. Maidenhead: McGraw-Hill, 2011.

Bourdieu, Pierre. Distinction: A Social Critique of the Judgement of Taste. Cambridge, MA: Routledge and Kegan Paul, 1984.

Bourdieu, Pierre. "The Forms of Capital," In Handbook of Theory and Research for the Sociology of Education, edited by John G. Richardson. New York: Greenwood Press, 1986.

Bourdieu, Pierre. "What Makes a Social Class? On the Theoretical and Practical Existence of Groups," Berkeley Journal of Sociology 32 (1987): 1-17.

Bowell, Tracy. "Feminist Standpoint Theory," The Internet Encyclopedia of Philosophy, 2020, https://iep.utm.edu/fem-stan/.

Brennan, Jason. Against Democracy. Princeton, NJ: Princeton University Press, 2016.

Dixon, John. "Dialogue and Theory: On James Moffett's Work in English Teaching and Language Education," Teaching English 17, no. 3 (2010): 275-284.

Haider, Asad, and Salar Mohandesi. "Worker's Inquiry: A Genealogy," Viewpoint Magazine 3, (2013).

Hasan, Ruqaiya. "The Ontogenesis of Decontextualized Language: Some Achievements of Classification and Framing," In Semantic Variation: Meaning in Society and Sociolinguistics, edited by Jonathan J. Webster. London: Equinox, 2009.

Heidegger, Martin. Being and Time. Oxford: Blackwell, 1962.

Jaeggi, Rahel. Critique of Forms of Life. Cambridge, MA: Harvard University Press, 2018. James, James. “The Sentiment of Rationality," Mind 4, no. 15 (1879): 317-346.

Kidd, Ian J., José Medina, and Gaile Pohlhaus, Jr. The Routledge Handbook of Epistemic Injustice. Oxon, UK: Routledge, 2017.

Kögler, Hans Herbert. "Alienation as Epistemological Source: Reflexivity and Social Background after Mannheim and Bourdieu," Social Epistemology 11, no. 2 (1997): $141-164$. 
Lai, Cynthia. "The Role of Practice in the Marxist Theory of Knowledge," The 80's 2, no. 1 (1981), https://www.marxists.org/history/erol/ncm-8/cwppractice.htm\#: :text= The $\% 20$ Marxist $\% 20$ line $\% 20$ of $\% 20$ cognition, and $\% 20$ methods $\% 20$ of $\% 20$ the $\% 20$ proletariat.

Latour, Bruno. "Why Has Critique Run Out of Steam? From Matters of Fact to Matters of Concern," Critical Inquiry 30 (Winter 2004): 225-248.

Law, Carolyn Leste. "Introduction," In This Fine Place So Far from Home: Voices of Academics from the Working Class, edited by C. L. Barney Dews and Carolyn Leste Law. Philadelphia, PA: Temple University Press, 1995.

Lawson, Tony. "Economic Science without Experimentation," In Critical Realism: Essential Readings, edited by Margaret Archer, Roy Bhaskar, Andrew Collier, Tony Lawson, and Alan Norrie. Abingdon: Routledge, 1998.

Lukács, György. History and Class Consciousness: Studies in Marxist Dialectics. London: Merlin Press, 1971 [1920].

MacIntyre, Alisdair. Three Rival Versions of Moral Enquiry: Encyclopedia, Genealogy and Tradition. Notre Dame, IN: Notre Dame University Press, 1990.

Moffett, James. Teaching the Universe of Discourse: A Theory of Discourse. Boston, MA: Houghton Mifflin, 1968.

Peckham, Irvin. "Complicity in Class Codes: The Exclusionary Function of Education," In This Fine Place So Far from Home: Voices of Academics from the Working Class, edited by C. L. Barney Dews and Carolyn L. Law. Philadelphia, PA: Temple University Press, 1995.

Pohl, Kerstin, and Klaus-Peter Hufer. "An Interview with Oskar Negt," International Labor and Working-Class History 90 (Fall 2016): 203-207.

Radcliffe, Barbara. "Narrative as a Springboard for Expository and Persuasive Writing: James Moffett Revisited." Voices from the Middle 19, no. 3 (2012): 18-24.

Rorty, Richard. Philosophy and the Mirror of Nature. Princeton, NJ: Princeton University Press, 1979.

Savage, Mike, Niall Cunningham, Fiona Devine, Sam Friedman, Daniel Laurison, Lisa McKenzie, Andrew Miles, Helene Snee, and Paul Wakeling. Social Class in the 21st Century. St Ives, UK: Penguin Random House, 2015.

Silverman, David. Qualitative Methodology \& Sociology: Describing the Social World. Aldershot, UK: Gower, 1985.

Willsher, Kim. "Didier Eribon, Writer: 'What Was Difficult Was Not Being Gay but Being Workingclass'.” The Guardian, May 27, 2018, https://www.theguardian.com/ books $/ 2018 / \mathrm{may} / 27 /$ didier-eribon-interview-returning-toreims-working-classcoming-out--memoir.

Woodcock, Jamie. “The Workers' Inquiry from Trotskyism to Operaismo: A Political Methodology for Investigating the Workplace," Ephemera: Theory and Politics in Organization 14, no. 3 (2014): 493-513. 
